\title{
PENINGKATAN HASIL BELAJAR IPA BIOLOGI MELALUI PENERAPAN STRATEGI JIGSAW PADA SISWA KELAS XI MA YAHBON TOLLU KECAMATAN CAMBA KABUPATEN MAROS TAHUN 2019
}

\author{
Anita $\mathbf{H}^{1}$, Suci Wirahayu ${ }^{2}$ \\ ${ }^{1}$ STKIP YAPTI Turatea Jeneponto \\ ${ }^{2}$ MA YAHBON Tollu Maros \\ anitahakim27@gmail.com
}

\begin{abstract}
ABSTRAK
Penelitian ini dilakukan untuk mendapatkan informasi mengenai peningkatan hasil belajar siswa dalam pembelajaran biologi melalui penerapan strategi jigsaw di MA Yahbon Tollu, Kecamatan Camba Kabupaten Maros. Subjek penelitian ini adalah Siswa kelas XI dengan jumlah siswa sebanyak 36 orang. Teknik pengumpulan data yang digunakan untuk mengetahui peningkatan hasil belajar siswa adalah dengan menggunakan analisis tes hasil belajar. Temuan analisis tes hasil belajar melalui penerapan strategi jigsaw diperoleh hasil tes sudah memenuhi ketuntasan belajar dengan jumlah siswa yang tuntas belajar sebanyak $88,89 \%$ dan berdasarkan skor gain ternormalisasi pembelajaran ini mempunyai nilai $0,31 \%$ yang tergolong kategori efektivitas sedang. Hal ini menunjukkan bahwa penerapan strategi jigsaw yang dikembangkan pada penelitian ini cukup efektif. Dengan demikian dapat disimpulkan bahwa terdapat peningkatan hasil belajar setelah menggunakan strategi jigsaw pada pembelajaran Biologi di MA Yahbon Tollu Kecamatan Camba Kabupaten Maros.
\end{abstract}

\section{ABSTRACT}

This research was conducted to obtain information about improving student learning outcomes in biology learning through the implementation of a jigsaw strategy at MA Yahbon Tollu, Camba District Maros Regency. The subjects of this study were class XI students with 36 students. Data collection techniques used to determine the improvement of student learning outcomes is to use the analysis of learning outcomes tests. The findings of the analysis of learning outcomes tests through the implementation of the jigsaw strategy obtained test results have met the completeness of learning with the number of students who have completed learning as much as $88.89 \%$ and based on this learning normalized gain score has a value of $0.31 \%$ which is classified as moderate effectiveness category. This shows that the application of the jigsaw strategy developed in this study is quite effective. Thus it can be concluded that there is an increase in learning outcomes after using a jigsaw strategy in learning Biology in MA Yahbon Tollu Camba District Maros Regency.

Keywords: Strategies of Learning Jigsaw; Improved Learning Outcomes

\section{Pendahuluan}

Pendidikan merupakan hal yang penting bagi setiap manusia agar dapat hidup dengan keahliannya yang merupakan sumber daya dan akan menuntun dalam kehidupan di masyarakat. Peningkatan kualitas pendidikan merupakan salah satu cara yang efektif dalam meningkatkan kualitas sumber daya manusia suatu bangsa. Semakin maju kualitas pendidikan suatu negara, maka semakin tinggi kualitas bangsa itu. Tidak ada suatu negara maju yang memiliki mutu pendidikan yang rendah. Seperti halnya Jepang dan Amerika Serikat adalah negara yang mempusatkan sistem politiknya dalam bidang pendidikan yaitu dengan cara menekankan pendidikan sebagai prioritas utama dalam pembangunan negaranya (Rasyidin, 2016).

Indikator lemahnya sistem pendidikan dapat dilihat dari kurang berhasilnya proses pembelajaran. Usaha dan keberhasilan belajar dipengaruhi oleh banyak faktor. Waluyo (2015) menyatakan bahwa faktor-faktor yang mempengaruhi usaha dan keberhasilan belajar dapat bersumber pada diri siswa atau lingkungan siswa. Belajar perlu didukung oleh motivasi yang kuat dan konstan. Motivasi yang lemah dan tidak konstan akan menyebabkan kurangnya usaha belajar, yang pada akhirnya akan berpengaruh terhadap hasil belajar.

Beragam metode dan model pembelajaran dapat digunakan untuk menampilkan materi pembelajaran Biologi di sekolah. Proses pembelajaran Biologi di sekolah masih cenderung menggunakan teacher centered. Pada pembelajaran kelas, guru lebih senang menggunakan metode konvensional, siswa hanya menjadi objek pendidikan tanpa memperhatikan berbagai karakteristik dan emosi yang dimiliki oleh siswa itu sendiri, sehingga siswa menjadi kurang termotivasi dan pasif. Dari hasil pengamatan diketahui kebanyakan siswa belum belajar sewaktu guru mengajar, sehingga tingkat pemahaman siswa rendah. Seharusnya belajar mengajar merupakan kegiatan aktif siswa dalam membangun makna atau pemahaman. Guru perlu memberikan dorongan kepada siswa untuk menggunakan hak belajarnya dalam membangun gagasan sehingga siswa menjadi aktif. Guru berkewajiban menciptakan situasi yang mendorong aktif, kreatif dan inovatif. Belajar adalah suatu proses perubahan tingkah laku seseorang yang merupakan 
hasil interaksi dengan lingkungan untuk memenuhi kebutuhan hidupnya. Perubahan tingkah laku sebagai hasil belajar meliputi seluruh aspek kepribadian, mencakup perubahan fisik dan psikis seperti perubahan dalam pengertian pemecahan masalah, sikap, keterampilan, kebiasaan, kecakapan, pengetahuan dan sebagainya (Waluyo, 2015).

Suasana belajar yang tidak kondusif menyebabkan siswa kurang dapat menangkap dengan baik materi yang diberikan oleh guru dan cenderung enggan untuk menyampaikan pemikiran mereka sendiri. Dalam proses pembelajaran interaksi antara guru dengan siswa kurang lancar apalagi interaksi atar siswa hampir tidak terjadi. Hal ini menyebabkan siswa kurang termotivasi untuk belajar. Dampak dari semua itu minat belajar siswa menjadi rendah dan pada akhirnya berdampak pada hasil belajar siswa yang jauh dari harapan.

Salah satu upaya untuk merubah kondisi tersebut adalah melalui penerapan strategi jigsaw. Hal ini sesuai dengan hasil penelitian Sulastri dan Rochintaniawati (2009) bahwa penerapan pembelajaran kooperatif dengan strategi jigsaw dapat meningkatkan hasil belajar siswa. Menurut Wartono, dkk, (2004) pembelajaran kooperatif merupakan suatu model pengajaran dimana siswa belajar dalam kelompok-kelompok kecil yang memiliki tingkat kemampuan berbeda. Dalam menyelesaikan tugas kelompok, setiap anggota saling bekerja sama dan membantu untuk memahami suatu bahan pembelajaran. Sedangkan menurut Kunandar (2007), pembelajaran kooperatif adalah pembelajaran yang secara sadar dan sengaja mengembangkan interaksi yang saling asuh antar siswa untuk menghindari ketersinggungan dan kesalahpahaman yang dapat menimbulkan permusuhan.

Terdapat banyak tipe dalam pembelajaran kooperatif Salah satunya adalah tipe jigsaw yang dikembangkan oleh Aronson et al, Menurut Lie (2002), dalam teknik ini guru harus memperhatikan pengetahuan dan pengalaman siswa dan membantu siswa mengaktifkan pengetahuan dan pengalaman itu agar bahan-bahan pelajaran menjadi lebih bermakna. Siswa juga harus bekerja sama dengan siswa lain dalam suasana gotong royong dan mempunyai banyak kesempatan untuk mengolah informasi dan meningkatkan keterampilan berkomunikasi. Menurut Waluyo (2015), Pembelajaran kooperatif jigsaw membagi siswa menjadi beberapa kelompok dengan karakteristik yang heterogen. Anggota dari berbagai kelompok yang berbeda memiliki tanggung jawab untuk mempelajari suatu bahan materi yang sama dan selanjutnya berkumpul dalam kelompok ahli untuk saling membantu mengkaji bagian bahan tersebut. Selanjutnya siswa yang berada dalam kelompok ahli kembali ke kelompok semula untuk mengajar anggota lain mengenai materi yang telah dipelajari dalam kelompok ahli. Siswa dievaluasi secara individual mengenai bahan yang telah dipelajari setelah diadakan diskusi.
Berdasarkan Latar Belakang yang telah diuraikan di atas maka dilakukan penelitian untuk membuktikan bahwa "Penerapan strategi jigsaw dapat meningkatkan hasil belajar siswa dalam pembelajaran Biologi di SMA Yahbon Tollu Kecamatan Camba Kabupaten Maros". Asumsi yang melandasi penelitian ini adalah pembelajaran kooperatif dengan menggunakan strategi jigsaw memberikan peluang kepada siswa untuk mengembangkan kemampuan verbal dan pemahaman terhadap materi secara interaksional sehingga para siswa lebih mampu untuk menangkap setiap informasi yang disajikan dari materi pembelajaran dan pada akhirnya akan meningkatkan hasil pembelajaran para siswa. Berdasarkan asumsi tersebut, maka hipotesis dalam penelitian ini adalah Penerapan Strategi Jigsaw dapat meningkatkan hasil belajar Biologi Siswa MA Yahbon Tollu kecamatah Camba Kabupaten Maros.

Tujuan penelitian ini adalah untuk mengetahui apakah pembelajaran kooperatif dengan strategi jigsaw dapat meningkatkan hasil belajar Biologi Siswa MA Yahbon Tollu kecamatah Camba Kabupaten Maros Sedangkan manfaat yang diharapkan dari penelitian ini adalah diperolehnya strategi pembelajaran yang tepat untuk menunjang potensi dalam mengembangkan pengetahuan serta peningkatan mutu pendidikan di Kabupaten Maros.

\section{Metode Penelitian}

Penelitian ini menggunakan metode Weak eksperimen (eksperimen semu). Desain penelitian yang digunakan adalah One Group Pretes-Postes dimana terlebih dahulu dilakukan tes awal untuk mendapatkan data hasil belajar siswa sebelum dilakukan pembelajaran kooperatif dengan strategi jigsaw kemudian setelah itu dilakukan tes akhir untuk mengetahui sejauh mana perkembangan hasil belajar siswa setelah dilakukan pembelajaran kooperatif dengan strategi jigsaw.

\begin{tabular}{|l|l|l|}
\hline $\mathrm{X} 1$ & $\mathrm{O}$ & $\mathrm{X} 2$ \\
\hline
\end{tabular}

\section{Keterangan :}

$\mathrm{X}=$ Pre Tes (tes awal)

$\mathrm{O}=$ Penerapan Strategi Jigsaw

$\mathrm{X} 2=$ Post Tes (tes akhir)

Subjek penelitian ini adalah siswa kelas XI MA Yahbon Tollu kecamatah Camba Kabupaten Maros yang berjumlah 36 orang dengan rincian 14 orang siswa laki-laki dan 22 orang siswa perempuan. Pengumpulan data dilakukan dengan tes pilihan ganda untuk mendapatkan data mengenai penguasaan terhadap materi sistem gerak manusia.

Standar Ketuntasan Belajar Minimal (SKBM) MA Yahbon ditetapkan sebesar $\geq 60$ sehingga untuk dapat dikatakan tuntas belajar maka siswa minimal harus mendapatkan nilai 60 .

Dalam penelitian ini, peningkatan hasil belajar juga dihitung dengan menggunakan uji normalitas gain untuk mengetahui apakah terdapat perbedaan yang signifikan antara pre tes dan pos tes 
pada pembelajaran Biologi dengan menggunakan strategi jigsaw. Untuk menghitung nilai indeks gain sebagai indikator efektifitas pembelajaran yang telah dilakukan, digunakan perhitungan sebagai berikut :

$$
g=\frac{\text { nilai postes }- \text { nilai pretes }}{\text { nilai tertinggi postes }- \text { pretes }}
$$

Tingkat efektivitas pembelajaran dalam indeks gain dikategorikan sebagai berikut :

\begin{tabular}{lc}
\hline Nilai Indeks Gain & Kategori Efektivitas \\
\hline$>0,7$ & Tinggi \\
$0,3-0,7$ & Sedang \\
$<0,3$ & Rendah \\
\hline
\end{tabular}

\section{Hasil dan Pembahasan}

Hasil belajar diperoleh dengan melalui tes yang menggunakan soal pilihan ganda yang diberikan sebelum dan sesudah dilakukan penerapan pembelajaran kooperatif menggunakan strategi jigsaw. Berdasarkan data yang diperoleh ringkasan data nilai tes awal dan tes akhir sebagai berikut :

Tabel 1. Rekapitulasi Nilai Tes

\begin{tabular}{|l|c|c|c|}
\hline \multicolumn{1}{|c|}{ Data } & $\begin{array}{c}\text { Tes } \\
\text { Awal }\end{array}$ & $\begin{array}{c}\text { Tes } \\
\text { Akhir }\end{array}$ & $\begin{array}{c}\text { Gain } \\
\text { Normalized }\end{array}$ \\
\hline N & 36 & 36 & - \\
Nilai Max & 80 & 90 & - \\
Nilai Min & 42 & 56 & - \\
Rerata & 63,03 & 71,39 & 0,31 \\
SD & 11,12 & 10.02 & - \\
Tuntas & 23 & 32 & - \\
Tdk Tuntas & 13 & 4 & - \\
\hline
\end{tabular}

Pada Tes awal yang dilakukan terhadap 36 Siswa MA Yahbon Tollu kecamatah Camba Kabupaten Maros, diperoleh data nilai tertinggi yang didapatkan oleh siswa adalah 80 dan nilai terendah adalah 42 dengan rerata 63,03 dan standar deviasi (simpangan baku) $11,12 \%$. Jumlah siswa yang tuntas belajar sebanyak 23 siswa dan tidak tuntas belajar sebanyak 13 siswa.

Pada tes akhir setelah siswa diberikan pembelajaran kooperatif dengan menggunakan strategi jigsaw, diperoleh data nilai tertinggi yang didapatkan oleh siswa adalah 90 dan nilai terendah adalah 56 dengan rerata 71,39 dan standar deviasi (simpangan baku) 10,02. Jumlah siswa yang tuntas belajar sebanyak 32 siswa dan tidak tuntas belajar sebanyak 4 siswa.

Dengan demikian dapat disimpulkan bahwa terdapat perbedaan yang cukup signifikan terhadap hasil tes awal yang dilakukan dan tes akhir setelah siswa diberikan pembelajaran

Dalam aspek ketuntasan belajar, berdasarkan Standar Ketentuan Belajar Minimal (SKBM) Siswa MA Yahbon Tollu kecamatah Camba Kabupaten Maros siswa dapat dikatakan tuntas belajar setelah memperoleh nilai $\geq 60$. Pada kelas penelitian dari data hasil tes awal, jumlah siswa yang tuntas belajar sebanyak 23 siswa $(63,89 \%)$ dan siswa yang tidak tuntas belajar sebanyak 14 siswa $(36,11 \%)$ nilai tersebut belum memenuhi standar ketuntasan belajar secara klasikal yaitu sebesar $85 \%$. Setelah siswa diberikan pembelajaran kooperatif dengan menggunakan strategi jigsaw dan dilakukan tes akhir maka diperoleh data jumlah siswa yang tuntas belajar adalah sebanyak 32 siswa $(88,89 \%)$ dan siswa yang tidak tuntas belajar adalah 4 siswa $(11,11 \%)$. Dengan begitu persentase siswa yang tuntas belajar telah mencapai standar ketuntasan belajar yang ditetapkan.

Dari hasil uji normalitas gain diperoleh nilai gain ternormalisasi sebesar 0,31 . Nilai tersebut dalam pengkategorian efektivitas pembelajaran termasuk ke dalam kategori sedang. Hal ini menunjukkan bahwa pembelajaran kooperatif dengan menggunakan strategi jigsaw yang diterapkan cukup efektif dalam meningkatkan hasil belajar IPA Biologi Siswa MA Yahbon Tollu kecamatah Camba Kabupaten Maros Kelas XI.

\section{Kesimpulan}

Hasil penelitian menunjukkan bahwa nilai Siswa MA Yahbon Tollu kecamatah Camba Kabupaten Maros telah memenuhi standar ketuntasan belajar dengan persentase ketuntasan belajar sebesar $88,89 \%$. Dari uji normalitas gain diperoleh hasil gain ternormalisasi sebesar 0,31. Efektivitas pembelajaran dikategorikan kedalam kategori sedang. Hal ini menunjukkan bahwa penerapan strategi jigsaw yang dilakukan pada penelitian ini cukup efektif dalam meningkatkan hasil belajar Siswa MA Yahbon Tollu kecamatan Camba Kabupaten Maros.

\section{Dafar Pustaka}

Kunandar. Langkah Mudah Penelitian Tindakan Kelas sebagai Pengembangan Profesi Guru. Jakarta: PT Raja Grafido Persada. 2007.

Lie A. Cooperative Learning. Jakarta: Gramedia Widiasarana Indonesia. 2002.

Rasyidin R. Pengaruh Strategi Pembelajaran Kooperatif Tipe Jigsaw Terhadap Hasil Belajar Fisik Ditinjau dari Motivasi Belajar pada Pelajaran Fisika Siswa Kelas X SMA Negeri 1 Bontonompo. Makassar: Universitas Islam Negeri Alauddin. 2016.

Setiawan Y. Meningkatkan Minat Belajar Sejarah Siswa Kelas XI IPA 2 SMA N 1 Depok Tahun Ajaran 2011/2012 Melalui Penerapan Strategi Pembelajaran Kooperatif Teknik Jigsaw II. Yogyakarta: Universitas Negeri Yogyakarta. 2014.

Sulastri Y \& Rochintaniawati D.. Pengaruh Penggunaan Pembelajaran Kooperatif Tipe Jigsaw dalam Pembelajaran Biologi di SMPN 2 Cimalaka. Sumedang: Universitas Pendidikan Indonesia. 2009

Waluyo. Penerapan Pembelajaran Kooperatif Jigsaw dalam Meningkatkan Hasil Belajar Biologi di Kelas XII IPA 1 SMA Negeri 5 Palembang Tahun Pelajaran 2014/2015. Palembang: Jurnal 
ISSN 2406-8233

Pembelajaran Biologi, Volume 2, Nomor 1, Mei 2015. 2015.

Wartono, dkk Materi Pelatihan Terintegrasi Sains.

Jakarta: Depertemen Pendidikan Nasional. 2004. 